DOI https://doi.org/10.18551/rjoas.2017-11.53

\title{
GROWTH OF LUJA PLANTS (PERISTRHOPHE BIVALVIS MERRILL) AT DIFFERENT LIGHT INTENSITIES AND MATERIAL TYPES OF CUTTINGS
}

\author{
Melati Rima* \\ Faculty of Agriculture, University of Brawijaya, Indonesia \\ Sugito Yogi, Aini Nurul, Nihayati Ellis \\ Department of Agricultural Cultivation, University of Brawijaya, Indonesia \\ *E-mail: rima tafure@yahoo.com
}

\begin{abstract}
Light intensities and planting materials of cuttings are two critical factors affecting plant growth. This research was aimed to find out the effects of light intensities and planting material types of cuttings affecting the growth of Luja plants. The light intensity treatments consisted of $100 \%, 65 \%, 35 \%, 15 \%$ and the planting material types covered both basal and tip cuttings. The design used was Split Plot Design and continued with Duncan's Test. The results showed that there was no interaction between light intensities and cuttings, but the effect of light intensities and cuttings was singularly found in the SLA, RGR, LAD, LAR, and NAR variables. Moreover, Luja plants could grow well at the light intensity of $15 \%-65 \%$ with the optimum light intensity of $35 \%$. Both basal and tip cuttings could be used as the planting materials. However, the material type of cuttings that could accelerate the vegetative phasegrowth of Luja plants the most was tip cuttings. Luja is categorized as a plant that can grow in full light conditions.
\end{abstract}

\section{KEY WORDS}

Luja, growth rate, light intensity, cuttings.

Before the presence of synthetic dyes, Luja plants (Peristrhophe bivalvis Merrill) has often been utilized and used by craftsmen as the raw material of fiber dyes in Maluku Province, Indonesia (Melati, 2016). In Vietnam, it is even used for food coloring (Dang et al., 2014). To date, the utilization of Luja is only explorative. Luja is classified as a wild plant. The results of the research on growing habitats and other cultivation aspects have not been examined further in Indonesia, so there is no clear technical guidance on growth requirements. The purpose of this research was to find out the optimum light intensity and appropriate cutting material type for Luja growth. The intensity of light plays an essential role in plant metabolism, affecting the plant growth at the beginning of nursery (Mukhtar, 2016). Previous research has suggested that some of the factors that can influence the plant pigment resulted are light (Sirait, 2008; Ferus and Arkosiova, 2001), as well as the quantity and quality of the plant (Moacyr et al., 2000; Fu et al., 2012).

Different parts of cuttings give effects at the beginning stage of growth to production. Tip cuttings are recommended for growing plants by concerning on the position of the cuttings, the number of nodules, particularly in some plants such as Stevia Rebaudiana Bertoni, Alstonia scholaris (L.) R., sweet potatoes, Plectranthus vettiveroides (Mashudi and Adinugraha, 2015; Mardi et al., 2016). The intensity of light is an environmental factor that must be regulated under low conditions to support the initial growth of cuttings without limiting the process of photosynthesis (Tombosi et al., 2015). This is because light can provide a stimulus to the apical tissue enlargement, biomass formation, leaf area and even the visible plant pigment on the plant growth itself (Rozali et al., 2011 ; Mauro et al., 2011 ; Zervoudakis et al., 2012 ; Gulshan et al., 2012 ; Safeer et al., 2013).

Biomass allocation in each organ of plants varies depending on the species and shade percentages (McAlpine \& Jesson, 2007; Devkota \& Jha, 2010; Santelices et al., 2015). 


\section{METHODS OF RESEARCH}

This experiment was conducted using pots in Dadaprejo Subdistrict, Batu City, East Java at an altitude of $450 \mathrm{~m}$ asl (above sea level) and the biomass observation was performed in the laboratory of Environmental Resources, Faculty of Agriculture, Brawijaya University, which took place from October 2016 until January 2017. The treatment consisted of two factors namely light intensities (I) and planting materials (S) of cuttings. The light intensities covered $100 \%$ (I0), 65\% (I1), 35\% (I2) and 15\% (I3) while the planting materials of cuttings consisted of basal cuttings (S1) and tip cuttings (S2), resulting in a total of 8 treatments. The treatment combinations used in this experiment were $10 \mathrm{~S} 1(100 \%$ light intensity + basal cutting), I0S2 (100\% light intensity + tip cutting), I1S1 (65\% light intensity + basal cutting), I1S2 (65\% light intensity + tip cutting), I2S1 (35\% light intensity + basal cutting), I2S2 (35\% light intensity + tip cutting), I3S1 (15\% light intensity + basal cutting), I3S2 (15\% light intensity + tip cutting).

The basal cuttings (S1) were taken from the basal parts of the secondary branches (stems) which were cut by four internodes while tip cuttings (S2) were the tip parts of the secondary branches (stems) consisting of four internodes calculated from the bud. The design used in this research was Split Plot Design repeated 3 times and continued with Duncan's Test to determine the difference of each treatment at the confidence level of 0.05 varieties using a Genstat software. The plants were placed in a shaded area for 4 weeks and then transferred to the planting area following the treatments being experimented. A destructive observation was performed at 2 weeks since after that. The subsequent treatments and observation were made at the interval of 2 weeks until the plants reached the age of 12 weeks after the treatments. The destructive observation consisted of Specific Leaf Area (SLA), Relative Growth Rate (RGR), Leaf Area Duration (LAD), Leaf Area Ratio (LAR) and Net Assimilation Rate (NAR). The formulas used to calculate the SLA, RGR, LAD, LAR and NAR variables according to Uzun and Kar, 2004; James and Drenovsky, 2007; Sugito, 2009; Poorter et al., 2012; Sitompul, 2016 are as follows:

Specific Leaf Area (SLA). SLA is the formation of leaf area per assimilate substrate unit shaped or the depiction of leaf thickness. SLA is obtained from the ratio of Leaf Area / LA $(\mathrm{cm})$ to dry Leaf Weight/LW $(\mathrm{g})$. SLA observation was conducted as much as 6 times, covering at the ages of $2,4,6,8,10$ and 12 weeks after the treatments (wat) of transplanting:

$$
\mathrm{SLA}=\frac{L A}{L W}
$$

Relative Growth Rate (RGR). RGR is the index of plant growth obtained from the total dry weight of the plants / W (g) at a given period/ T (day) to determine the growth rate during the growing period. RGR observation was performed as much as 5 times with the observation intervals of 2-4 weeks, 4-6 weeks, 6-8 weeks, 8-10 weeks and 10-12 weeks after the treatments (wat) of transplanting.

$$
R G R=\frac{\ln W_{2}-\ln W_{1}}{T_{2}-T_{1}}
$$

Leaf Area Duration ( $L A D)$. LAD is the duration of the ability of leaf unit to do photosynthesis, determined by Leaf Area (LA) and Time (T). LAR observation was carried out as much as 5 times with the observation intervals of 2-4 wat, 4-6 wat, 8-10 wat, and 1012 wat.

$$
L A D=\frac{L A_{2}-L A_{1}}{\ln L A_{2}-\ln L A_{1}} \times\left(T_{2}-T_{1}\right)
$$


Leaf Area Ratio (LAR). LAR is the quality of light received by leaves to form the whole plant organs. LAR can be calculated by comparing the Leaf Area (LA) with the total dry Weight (W) of the plants. LAR observation was conducted as much as 5 times with the observation intervals of 2-4 wat, 4-6 wat, 6-8 wat, 8-10 wat, 10-12 wat.

$$
L A R=\frac{\mathrm{LA}_{2}-\mathrm{LA}_{1}}{\mathrm{~W}_{2}-\mathrm{W}_{1}} \times \frac{\ln \mathrm{W}_{2}-\ln \mathrm{W}_{1}}{\ln \mathrm{LA}_{2}-\ln \mathrm{LA}_{1}}
$$

Net Assimilation Rate (NAR). NAR is the ability of a unit of leaf area to produce biomass. NAR can be calculated by knowing the total dry Weight/ W (g), Leaf Area/ LA (cm), and observation Time/ T (days). NAR observation was performed as much as 5 times with the observation intervals of 2-4 wat, 4-6 wat, 6-8 wat, 8-10 wat, and 10-12 wat.

$$
N A R=\frac{W_{2}-W_{1}}{L A_{2}-L A_{1}} \times \frac{\ln L A_{2}-\ln L A_{1}}{T_{2}-T_{1}}
$$

\section{RESULTS AND DISCUSSION}

Specific Leaf Area (SLA). In this research, the interaction between light intensities and planting material types of cuttings did not influence the growth of Luja plants. The effect of light intensities on the SLA was seen at all observation times, except 8 wat (Table 1). Luja plants exposed to the light intensity of $15 \%$ had a higher SLA value and were different from other treatments at the ages of 2 and 4 wat. In the other hand, Luja plants exposed to the light intensity of $35 \%$ obtained the highest SLA value at the age of 6 wat. However, they showed insignificant differences from those exposed to the light intensities of $65 \%$ and $15 \%$ but indicated significant differences from those exposed to the light intensity of $100 \%$. Luja plants exposed to the light intensity of $15 \%$ had a higher SLA value and were different from the other treatments at the ages of 2 and 4 wat. At the age of 6 wat, the SLA of the plants exposed to the light intensity of $35 \%$ got the highest value and was the same with those exposed to the light intensity of $65 \%$ and $15 \%$ but different from those exposed to the $100 \%$ light intensity. The SLA values of all treatments began to decline at the age of 10 wat, but the SLA of the plants with the exposure of $35 \%$ light intensity obtained the highest and consistent value. This research is similar to the previous research on Taxus baccata $\mathrm{L}$. plants that are tolerant to low light intensities and positively influence the SLA, leaf area, total chlorophyll, and, in contrast, give an adverse effect on the plant height and stem diameter (Perrin \& Mitchell, 2013). Besides, this research is also in line with research on low SLA values at high intensities for Ocimum basilicum L. plants (Caliskan et al., 2009). The genetic ability of Luja plants exposed to the low light intensities tended to widen the leaves to receive light. The plants located in the environments with limited light would use the light as efficiently as possible to form carbohydrates, which are characterized by higher SLA values that also can be used as the characteristics of shade-tolerant plants such as Nothofagus leonii (Santelices et al., 2015). Furthermore, according to Ma et al. (2015), plant performance will be different in shaded conditions, but the biomass and production under low light conditions will affect the carbohydrate production. Similarly, the coffee plants cultivated on a shaded land will have a higher SLA value than those cultivated on a full light-exposed land (Bote \& Struik, 2011). The part of the cuttings that affected the specific leaf area was only found at the age of 4 wat, and there was no significant effect on the subsequent observations. The cuttings derived from the base (basal cuttings) obtained higher SLA values than the tip cuttings. The growth rate of the basal cuttings could be seen towards the generative phase in which the formation of leaves and biomass was produced quite a lot, thus affecting the SLA values. The success of stem cuttings is also influenced by the ability and morphology of the stem of the plant itself. For example, the cultivation of fig tree (Ficus carica L) using a tip, middle, and basal 
cutting has the same statistical number of leaves at the ages of 2-10 weeks after planting (Yulistyani et al., 2014).

One of the growth indicators that were used as a measure in identifying the determinants of the growth and biomass of Luja plants was the specific leaf area. The quality and quantity of biomass produced were influenced by the number and size of the leaves. The habitats supporting the growth of Luja plants had low-light intensity conditions (shade plant), indicating that Peristrhophe bivalvis Merrill is tolerant to low light intensity although it also can grow in full light conditions. However, the increase in the leaf area was hampered by photo inhibition, resulting in smaller and fading leaves (Figure 1). The lower level of light intensity occurred in a more extensive leaf area. The same research result is also found on three varieties of Dracaena sanderiana with a larger leaf area at $50 \%-70 \%$ shade. Higher shade levels will result in a larger leaf area on the three species of grass (Sirait, 2008; Srikrishnah and Sutharsan, 2012). Besides, the genetic factors of the plants also determine the limits of light absorption (Sevik et al., 2012). Furthermore, stem-tip and basal cuttings planted in full and shaded light intensities show different growths, in which the tip cuttings of Plectranthus vettiveroides plants also successfully grow if they are in shaded conditions. (Safeer et al., 2013). The more excellent SLA value was, the thinner the Luja leaves would become. It is affected by the ability of leaves to enlarge the leaf tissue and allow light that enters the plant canopy as efficient as possible. This research is in line with the previous research on Taxus baccata L. plants, which are tolerant to low light intensities and positively influence the SLA, leaf area, total chlorophyll, and, in contrast, give an adverse effect on the plant height and stem diameter (Perrin \& Mitchell, 2013). Besides, this research is also similar to the previous research on low SLA values at high intensities for Ocimum basilicum L.plants (Caliskan et al., 2009).

Table 1 - Effect of Light Intensity and Planting Material on Specific Leaf Area (SLA) at the age of 2, 4, 6, 10 and 12 Weeks after Treatments (wat)

\begin{tabular}{cccccc}
\hline \multirow{2}{*}{ Light Intensity } & \multicolumn{5}{c}{ Average Specific Leaf Area $(\mathrm{cm} / \mathrm{g} / \mathrm{t})$} \\
\cline { 2 - 6 } & 22 wat & 4 wat & 6 wat & 10 wat & 12 wat \\
\hline $100 \%$ & $2245^{\mathrm{a}}$ & $166.49^{\mathrm{a}}$ & $150.69^{\mathrm{a}}$ & $131.69^{\mathrm{a}}$ & $119.12^{\mathrm{a}}$ \\
$65 \%$ & $233.26^{\mathrm{a}}$ & $166.01^{\mathrm{a}}$ & $196.50^{\mathrm{b}}$ & $138.53^{\mathrm{a}}$ & $150.60^{\mathrm{a}}$ \\
$35 \%$ & $290.52^{\mathrm{a}}$ & $207.18^{\mathrm{b}}$ & $232.20^{\mathrm{b}}$ & $214.27^{\mathrm{b}}$ & $213.01^{\mathrm{b}}$ \\
$15 \%$ & $303.80^{\mathrm{b}}$ & $242.71^{\mathrm{c}}$ & $213.00^{\mathrm{b}}$ & $210.69^{\mathrm{b}}$ & $207.64^{\mathrm{b}}$ \\
\hline Planting Material & & & & $\mathrm{ns}$ \\
\hline Basal Cutting & $\mathrm{ns}$ & $208.14 \mathrm{~b}$ & $\mathrm{~ns}$ & $\mathrm{~ns}$ & $\mathrm{~ns}$ \\
Tip Cutting & $\mathrm{ns}$ & $183.06^{\mathrm{a}} \mathrm{a}$ & $\mathrm{ns}$ & $\mathrm{ns}$ & $\mathrm{ns}$ \\
\hline
\end{tabular}

Description: The numbers followed by the same letters are not significantly different based on Duncan's Test at the 0.05 level; wat = weeks after treatment; $n s=$ not significant.

Relative Growth Rate (RGR). In addition to SLA, the other indicator used to examine the growth of Luja plants in this research was the relative growth rate. The results of the variances found that the growth rate of Luja plants to the relative growth rate did not show an interaction between light intensities and planting materials of cuttings. The light intensities influenced the relative growth rate at the ages of 2-4 wat and 4-6 wat. In another side, the sections of cuttings showed its effects at the age of 4-6 wat (Table 2) while, at the other observation intervals, there was not found any significant difference. The plants exposed to the light intensities of $65 \%, 35 \%$, and $15 \%$ differed significantly with those exposed to the light intensity of $100 \%$ (no shade) with the observation interval between 2-4 wat. In this phase, the highest RGR value was obtained at the light intensity of $15 \%$. In contrast, entering the generative phase (aged 4-6 wat), the plants exposed to the light intensity of $100 \%$ got the highest RGR value compared to other treatments. The growth rate of Luja plants in shaded conditions at the beginning of growth was faster than that in unshaded conditions. However, the plants exposed to $100 \%$ light intensity began to adapt in the second month because of the influence of the biomass produced. Each herbaceous species has a different response to the growth rate of plants (Fini et al., 2010). In shrubs, the highest relative growth rate was obtained in shaded conditions compared to the condition of full light intensity at the nursery 
phase (Hastwell and Facelli, 2003). Hevea brasiliensis without shades at the age of 0-7 months after planting has a higher RGR value than those with shades of $33 \%, 55 \%$, and $77 \%$. However, the RGR values among the treatments are not different when the plants are at the age of 7-14 months after planting (Senevirathna et al., 2003). As for Adansonia digitata plants, the highest RGR value is at $25 \%$ light intensity compared to $50-100 \%$ light intensities but among the treatments are not significantly different (Mukhtar, 2016). According to Wersal and Madsen (2013), aquatic plants of Myriophyllum aquaticum also have a high total RGR value in shaded conditions of $30 \%-70 \%$, affecting the physiological process that gives impacts on the difference in biomass among the plants exposed to full light intensity. Moreover, there is also a tendency to RGR increase of P.notatum and S.secundatum if placed in shaded conditions (Sirait, 2008). Each plant species has a different RGR value during the growing period in the forest area (Lamers et al., 2006) and there is a positive relationship between the shaded plants and the values of RGR and LAR (Portsmuth and Niinemets, 2007).

Leaf Area Duration (LAD). The results of the variances found that there was no interaction between light intensities and material types of cuttings on the LAD variable but what made effects was a single factor. The light intensities did not affect at the age of 2 wat while the material types of cuttings showed significant differences between the basal cuttings and tip cuttings in which the tip cuttings obtained a higher value of LAD than basal cuttings. The light intensity of $35 \%$ got a high and consistent LAD value at each observation interval although it was not different from the results of $100 \%$ light intensity at the observation intervals of 4-6 wat and 6-8 wat. The plants exposed to $15 \%$ light intensity had the lowest LAD value and were not significantly different from those exposed to $65 \%$ light intensity at each observation interval. This indicated that the duration of Luja leaf area at the light intensity of $35 \%$ was more active or longer to photosynthesis than that of other treatments (Table 2). The value of LAD depends on the growth rate and the adaptability of the plant itself. The results of this research are supported by the previous research stating that LAD has a positive correlation with the plant growth and yield, and depends on the genotype of the plant itself (Hunkova et al., 2011). Moreover, this research found that the plant age also determined the LAD for each treatment and it seemed that the highest LAD achievement was at the observation interval of 8-10 wat. However, the LAD value experienced a decline after entering the aging phase. The similar case is also found in some cereal plants that have different LAD values depending on the types and ages of the plants (Verma et al., 2016).

Net Assimilation Rate (NAR). Light plays an important role in improving plant biomass. In another side, Net Assimilation Rate (NAR) becomes an indicator in examining the effect of light on plant growth rates. Plant propagation by cutting techniques should take into account the optimum growing conditions supporting the growth of the nursery phase, vegetative growth to production. The results of this experiment showed that there was no interaction between light intensities and material types of cuttings affecting the net assimilation rate of Luja plants. However, it was found a separated effect of light intensities. The different light intensities affected the value of NAR at the ages of 4-6 wat and 8-10 wat, while the effect of the cuttings was seen at the age of 8-10 wat (Table 2).

Table 2 - Effect of Light Intensity and Planting Material on Leaf Area Duration and Net Assimilation Rate at the age of 2-12 wat

\begin{tabular}{|c|c|c|c|c|c|c|c|c|c|}
\hline \multirow{2}{*}{ Light Intensity } & \multicolumn{2}{|c|}{ Average Relative Growth Rate (g/t) } & \multicolumn{5}{|c|}{ Average Leaf Range Duration (cm.week) } & \multicolumn{2}{|c|}{$\begin{array}{l}\text { Average Net Assimilation } \\
\text { Rate }(\mathrm{g} / \mathrm{cm} / \mathrm{t})\end{array}$} \\
\hline & 2-4 wat & 4-6 wat & $2-4$ wat & 4-6 wat & $6-8$ wat & $8-10$ wat & $10-12$ wat & 4-6 wat & 8-10 wat \\
\hline $100 \%$ & $0.03^{a}$ & $0.12 \mathrm{~b}$ & \multirow{4}{*}{ ns } & $20983.00^{\circ}$ & $37722.00^{\mathrm{bC}}$ & $44336.00^{\circ}$ & $43749.00^{\circ}$ & $8.28 \mathrm{E}-04^{\circ}$ & $7.20 \mathrm{E}-05^{\mathrm{a}}$ \\
\hline $65 \%$ & $0.08^{\mathrm{b}}$ & $0.07 \mathrm{a}$ & & $17837.00^{\mathrm{ab}}$ & $31602.00^{\mathrm{ab}}$ & $36551.00^{\mathrm{ab}}$ & $32802.00^{\mathrm{a}}$ & $6.31 \mathrm{E}-04^{\mathrm{a}}$ & $6.30 \mathrm{E}-05^{\mathrm{a}}$ \\
\hline $35 \%$ & $0.07^{\mathrm{b}}$ & $0.08 \mathrm{a}$ & & $21226.00^{\mathrm{b}}$ & $38326.00^{c}$ & $53266.00^{\mathrm{c}}$ & $43498.00^{\mathrm{b}}$ & $1.53 \mathrm{E}-03^{\mathrm{c}}$ & $1.33 \mathrm{E}-04^{\mathrm{b}}$ \\
\hline $15 \%$ & $0.09^{\mathrm{b}}$ & $0.07 \mathrm{a}$ & & $13131.00^{\mathrm{a}}$ & $30552.00^{\mathrm{a}}$ & $32282.00^{\mathrm{a}}$ & $31620.00^{\mathrm{a}}$ & 6.66E-04 ab & $7.50 \mathrm{E}-05^{\mathrm{a}}$ \\
\hline \multicolumn{10}{|l|}{ Planting Material } \\
\hline $\begin{array}{l}\text { Basal Cutting } \\
\text { Tip Cutting }\end{array}$ & ns & $\begin{array}{l}0.10^{\mathrm{b}} \\
0.07^{\mathrm{a}}\end{array}$ & $\begin{array}{l}4844.00^{\mathrm{a}} \\
6908.70^{\mathrm{b}}\end{array}$ & \multicolumn{4}{|c|}{ ns } & ns & $\begin{array}{l}3.10 \mathrm{E}-05^{\mathrm{a}} \\
1.41 \mathrm{E}-04^{\mathrm{D}}\end{array}$ \\
\hline
\end{tabular}

Description: The numbers followed by the same letter are not significantly different based on Duncan's Test at the level of 0.05; wat = weeks after treatment; $n s=$ not significant. 
Luja plants exposed to $35 \%$ light intensity obtained the highest NAR value and were significantly different from other treatments at the ages of 4-6 wat and 8-10 wat. Meanwhile, there was a similarity between the plants received full light intensity (100\%) and those exposed to $15 \%$ light intensity but significantly different from those exposed to $65 \%$ light intensity at the observation interval of 4-6 wat. The plant growth in generative phase was different from the previous phase in which the highest NAR value was only found at the light intensity of $35 \%$ and significantly different from other treatments whereas the NAR values at the light intensities of $100 \%, 65 \%, 15 \%$ showed no difference. Adequate adaptability was shown by the high NAR values although the incoming light was blocked.

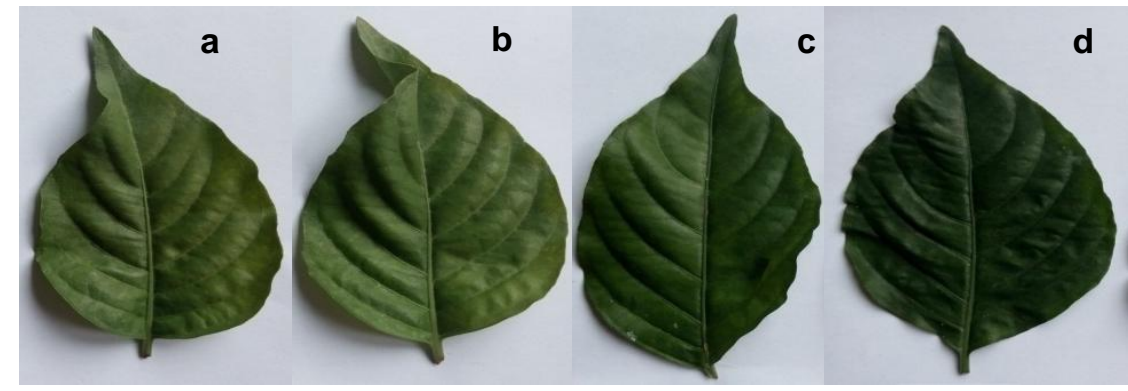

Figure 1 - Color Differences of Luja Leaves Based on Light Intensities:

$$
a=100 \%, b=65 \%, c=35 \%, d=15 \%
$$

The response of Luja plants to the limited light conditions was to enlarge the leaf area and increase the number of leaves. In other words, the low light intensity formed the plant character by absorbing the received light as much as possible, showing the darker leaf color or dark green (Figure 1). The similar thing is also found in Adansonia digitata (L.) plants that have the same NAR value when exposed to the light intensities of $25 \%-100 \%$, particularly at the time of nursery (Mukhtar, 2016). Differently, herbal plants of Epimedium pseudowushanense B.L.Guo exposed to a high light intensity $\left(90.9 \pm 2.5 \mu \mathrm{mol} . \mathrm{m}^{-}{ }^{2}\right.$.s $\left.{ }^{-1}\right)$ have a higher NAR value than those exposed to a low light intensity (Pan and Guo, 2016) and Trema micrantha (L.) Blume plants (Valio, 2001). Physiologically, there is a positive correlation between NAR, RGR and the area of leaves which actively carry out the process of photosynthesis in brushes during the initial growth originating from a tropical forest ( $\mathrm{Li}$ et al., 2016). Low light intensities vary for each type of plant to a certain limit (Sevik et al., 2012).

\section{CONCLUSION}

Light intensities and planting materials of cuttings are the growth requirement that must be considered in cultivating and propagating Luja plants. Luja plants can grow generally at the light intensity range of $15 \%-65 \%$ with the optimum light intensity of $35 \%$. However, the planting material that is able to encourage and accelerate the vegetative growth of Luja plants the most is tip cuttings.

\section{REFERENCES}

1. Abdullateef, R. A., \& M. Osman, 2012. Effects of Stem Cutting Types, Position and Hormonal Factors on Rooting in Stevia Rebaudiana Bertoni. Journal of Agricultural Science 4 (1): 49-57.

2. Afa, L.O. \& W.A. Sudarsono, 2014. Pengaruh Naungan terhadap Pertumbuhan dan Hasil Tanaman Kolesom (Talinum triangule (Jacq.) Willd), Agriplus 24 (2): 144-151.

3. Brito, S. L., C. L. Pinheiro, F. C. B. Nogueira, S. M. Filho and D. M. S. Matos de. 2015. Influence of light on the initial growth of invasive Cryptostegia madagascariensis Bojer in the Brazilian semiarid region, Acta Sci. Bio. Sciences 37 (3): 385-392. 
4. Buntoro, B.H., R. Rogomulyo \& S. Trisnowati, 2014. Pengaruh Takaran Pupuk Kandang dan Intensitas Cahaya Terhadap Pertumbuhan dan Hasil Temu Putih (Curcuma zedoaria L.). Vegetalika 3 (4): $29-39$.

5. Caliskan, O., M. S. Odabas \& C. Cirak, 2009. The Modeling of the Relation Among the Temperature and Light Intensity of Growth in Ocimum basilicum L. Journal of Medicinal Plants Research 3 (11): 965-977.

6. Dang B. K., Dam S. M., Pham M. T., Dang T. B. O \& Le T. H.V., 2014. Peristrophe Roxburghiana - A Review. Annals. Food Science and Technology 15 (1): 1-9.

7. Devkota, A \& P. K. Jha, 2010. Effects pf Deifferent Light Level on the Trairs and Yield of Centella asiatica. Middle-East Journal of Scientific Research 5 (4): 226-230.

8. Fauzi, R., Meiriani \& A. Barus. 2016. Pengaruh Persentase Naungan Terhadap Pertumbuhan Bibit Mucuna bracteata D.C. Asal Setek dengan Konsentrasi IAA yang Berbeda, Jurnal Agroekoteknologi 4 (3): 2114-2126.

9. Ferus, P \& Arkosiová, 2001. Variability of Chlorophyll Content under Fluctuating Environment " Proceedings of the International Scientific Conference on the Occasion of the 55th Anniversary of the Slovak Agricultural University in Nitra" . Acta fytotechnica et zootechnica (4): 123-125.

10. Fini, A., F. Ferrini, P. Frangi, G. Amoroso \& C. Giordano, 2010. Growth, Leaf Gas Exchange and Leaf Anatomy of Three Ornamental Shrubs Grown Under Different Light Intensities. Europ.J.Hort.Sci., 75 (3): 111-117.

11. Fu, W., P. Li, Y. Wu, \& J. Tang, 2015. Effects of Different Light Intensities on Antioxidative Enzyme Activity, Quality and Biomass in Lettuce. Sch. Acad. J. Biosci 3 (4): 392-396.

12. Gulshan, A. B., A.A. Dasti \& S. Shakoor, 2012. Eco-Physiological Traits NAR and LAR Role in Determining the Relative Growth Rate in Competition. Journal of Agricultural and Biological Scienc. 7 (10): 803-813.

13. Hastwell, T. H \& J. M. Facelli, 2003. Differing Effects of Shade-Induced Facilitation on Growth and Survival During the Establishment of a Chenopod Shrub. Journal of Ecology 2003 (91): 941-950.

14. Hlatshwayo, M. S \& P. K. Wahome, 2010. Effects of Shading on Growth, Flowering and Cut Flower Quality in Carnation (Dianthus caryohyllus). J. Agric. Soc. Sci., (6): 34-38.

15. Hunkova, E., M. Zivcak, K. Olsovka. 2011. Leaf Area Duration of Oilseed Rape (Brassica napus subsp. napus) Varieties and Hybrids and Its Relationship to Selected Growth and Productivity Parameters, Journal of Central European Agriculture 12 (1):1-15.

16. James, J. J. \& R. E. Drenovsky, 2007. A Basis for Relative Growth Rate Differences Between Native and Invasive Forb Seedlings. Rangeland Ecol Manage (60):395-400.

17. Jurami, A. S., D.S.H Drennan \& N. Anuar, 2004. The Effects of Shading on the Growth, Development of Biomass in Bermudagrass (Cynodon dactylon (L.) Pers.). Journal of Biological Sceinces 4 (6): 756-762.

18. Lamers, J. P. A., A. Khamzina \& M. Worbes, 2006. The Analyses of Physiological and Morphological Attributes of 10 Tree Species for Early Determination of Their Suitability to Afforest Degraded Landscapesin the Aral Sea Basin of Uzbekista. Forest Ecology and Management (221): 249-259.

19. Li, W., B. Schmid, F. Wang, \& C. E. T. Paine, 2016. Net Assimilation Rate Determines the Growth Rates of 14 Species of Subtropical Forest Trees. Plos One Journal 11 (3): 1 13.

20. Ma, J. Z., Z.J. Bu. X.X. Zheng, J.L. Ge \& S.Z. Wang, 2015, Effects of Shading on Relative Competitive Advantage of Three Species of Sphagnum. Mires and Peat, 16 (04): $1-17$.

21. Mardi, C.T., H. Setiado \& K. Lubis, 2016. Pengaruh Asal Stek dan Zat Pengatur Tumbuh Atonik Terhadap Pertumbuhan dan Produksi Dua Varietas Ubi jalar (Ipomoea batatas L.) Lamb. Jurnal Agroekoteknolog 4 (4): 2341-2348.

22. Mashudi \& H.A. Adinugraha, 2015. Kemampuan Tumbuh Stek Pucuk Pulai Gading (Alstonia scholaris (L.) R. Br.) dari Beberapa Posisi Bahan Stek dan Model Pemotongan Stek. Jurnal Penelitian Kehutanan Wallacea 4 (1): 63-69. 
23. Mauro, R.P., A. Occhipinti, A. M. G. Longo \& G. Mauromicale, 2011. Effects of Shading on Chlorophyll Content, Chlorophyll Fluorescence and Photosynthesis of Subterranean Clover. Journal of Agronomy and Crop Science (197): 57-66.

24. McAlpine, K.G., \& L. K. Jesson, 2007. Biomass Allocation, Shade Tolerance and Seedling Survival of the Invasive Species Berberis darwinii (Darwin's barberry). New Zealand Journal of Ecology 31(1): 1-12

25. Melati, R., 2016. Keragaman sumber pewarna nabati yang digunakan Oleh masyarakat Maluku Utara, Prosiding Seminar Nasional Pertanian "Optimalisasi Sumber Daya Lokal Berbasis Riset" Fakultas Pertanian Universitas Ternate, Cetakan Pertama p. 65-70.

26. Moacyr, B., Dias-Filho, \& A. F. C. Júnior, 2000. Growth, Biomass Allocation and Photosynthesis of Rolandra fruticosa (Asteraceae) in Response to Shade. Planta Daninha 18 (1): 71-78.

27. Mukhtar R.B., 2016. Influence of Light Intensity on Early Growth of Adansonia digitata (L.). Res. J. Recent Sci. 5(12): 5-9.

28. Musyarofah, N., S. Susanto, S. A. Aziz, \& S. Kartosoewarno, 2007. Respon Tanaman Pegagan (Centella asiatica L. Urban) Terhadap Pemberian Pupuk Alami di Bawah Naungan, Bul. Agron, 35 (3): $217-224$.

29. Pan, J \& B. Guo, 2016. Effects of Light Intensity on the Growth, Photosynthetic Characteristics, and Flavonoid Content of Epimedium pseudowushanense B.L.Guo. Molecules (21): 1-12.

30. Perrin, P.M \& F. J. G. Mitchell, 2013. Effects of shade on growth, biomass Allocation and leaf morphology in European yew (Taxus baccata L.). Ireland European Journal of Forest Research 132 (2): 211-218.

31. Poorter, H., K. J. Niklas, P. B. Reich, J. Oleksyn, P. Poot \& L. Mommer, 2012. Biomass Allocation to Leaves, Stems and Roots: Meta-Analyses of Interspecific Variation and Environmental Control. New Phytologist (193): 30-50.

32. Rozali, S. E., K. A. Rashid \& R. Farzinebrahimi, 2010. Effects of Shading Treatments on Pigmentation and Inflorescence Quality of Calathea crotalifera Bracts Int. J. Agric. Biol., Vol. 00, No. 0, 201x.

33. Safeer, P.M., S. Sreekumar, P. N. Krishnan, C. K. Biju \& G. Seeja. 2013. Influence of stem cuttings, spacing, group planting, light, irrigation and harvesting period on yield in Plectranthus vettiveroides (K.C. Jacob) N. P. Singh \& B. D. Sharma, Jour. of Agriculture and Veterinary Science 6 (3): 47-53.

34. Santelices, R., S. Espinoza \& A. M. Cabrera, 2015. Effects of Shading and Slow Release Fertilizer on Early growth of Nothofagus leonii Seedlings from Its Northernmost Distribution in Central Chile. Bosque 36(2): 179-185.

35. Sevik, H., D. Guney, H. Karakas \& G. Aktar. 2012. Change to Amount of Chlorophyll on Leaves Depend on Insolation in Some Landscape Plants. International Journal of Environmental Sciences 3 (3): 1057-1064.

36. Sirait,J., 2008. Luas Daun, Kandungan Klorofil dan Laju Pertumbuhan Rumput pada Naungan dan Pemupukan yang Berbeda. JITV 13 (2): 109-116.

37. Sitompul, S.M., 2016. Analisa Pertumbuhan Tanaman. Malang: UB Press.

38. Srikrishnah, S., S.E. Peiris \& S. Sutharsan, 2012. Effect of Shade Levels on Leaf Area and Biomass Production of Three Varieties of Dracaena sanderiana L. in the Dry Zone of Sri Lanka. Tropical Agricultural Research 23 (2): 142- 151.

39. Tombesi, S., A. Palliotti, S. Poni \& D. Farinelli. 2015. Influence of Light and Shoot Development Stage on Leaf Photosynthesis and Carbohydrate Status During the Adventitious Root Formation in Cuttings of Corylusavellana L. Frontiers in Plant Science (6): 1-13.

40. Uzun, S \& H. Kar, 2004. Quantitative Effects of Planting Time on Vegetative Growth of Broccoli (Brassica oleracea Var. Italica). J. Bot., 36 (4): 769-777.

41. Valio, I. F. M., 2001. Effects of shading and removal of plant parts on growth of Trema micrantha seedlings. Tree Physiology (21): 65-70. 
42. Verma, D., A.S. Gontia, A. Jha \& A. Deshmukh. 2016. Study on Leaf Area Index and Leaf Area Duration of Growth Analytical Parameters in Wheat, Barley, and Oat, International Journal of Agriculture, Environment and Biotechnology 9(5): 827-831.

43. Widiastuti L., Tohari \& E. Sulistyaningsih. 2004. Pengaruh Intensitas Cahaya dan Kadar Daminosida terhadap Iklim Mikro dan Pertumbuhan Tanaman Krisan dalam Pot, IImu Pertanian 11 (2): 53-42.

44. Yulistyani, W., D. S. Sobarna \& A. Nuraini. 2014. Pengaruh Jenis Stek Batang dan Komposisi Media Tanam terhadap Pertumbuhan Bibit Tanaman Ara (Ficus carica L.), Agric. Sci. J. 1 (4): 215-224.

45. Zervoudakis, G., G. Salahas, G. Kaspiris \& E. Konstantopoulo. 2012. Influence of Light Intensity on Growth and Physiological Characteristics of Common Sage (Salvia officinalis L.). Braz. Arch. Biol. Technol 55(1): 89-95.

46. Zheng, Y., W. Jiang, E. N. Silva, L. Mao, D.B. Hannaway \& H. Lu. 2012. Optimization of shade condition and harvest time for Dendrobium candidum plants basedon gas exchange, alkaloids and polysaccharides contents. Plants Omics Journal 5 (3):253-260. 